\title{
ANALISIS REGRESI PENAMPILAN BAWANG PUTIH SANGGA SEMBALUN DAN LUMBU KUNING SELAMA PENYIMPANAN DALAM SUHU RUANG
}

\author{
Regression Analysis of Appearance of Sangga Sembalun and Lumbu Kuning Garlic During \\ Storage in Room Temperature
}

\author{
Anna Sulistyaningrum ${ }^{*}$, Adhitya Marendra Kiloes ${ }^{1}$, Darudriyo ${ }^{2}$ \\ ${ }^{1}$ Pusat Penelitian dan Pengembangan Hortikultura \\ J1. Tentara Pelajar No. 3C Cimanggu, Bogor \\ ${ }^{2}$ Jurusan Agroteknologi Fakultas Pertanian Universitas Djuanda Bogor \\ Jl. Tol Ciawi No. 1, Kotak Pos 35, Ciawi Bogor 16720 \\ *Email : anna.sulistya@gmail.com
}

Diterima 21 Februari 2020/Disetujui 20 April 2020

\begin{abstract}
ABSTRAK
Bawang putih merupakan komoditas hortikultura yang memiliki nilai ekonomi tinggi dan banyak digunakan oleh masyarakat sebagai bumbu maupun obat. Bawang putih banyak mengalami perubahan baik secara nutrisional maupun penampakannya selama penyimpanan, sehingga dibutuhkan penanganan pascapanen yang tepat. Tujuan dari penelitian ini adalah mengetahui kualitas bawang putih Sangga Sembalun dan Lumbu Kuning yang disimpan dalam suhu ruang baik untuk konsumsi maupun benih serta mengetahui kualitas bawang putih dalam bentuk konde maupun rogol selama penyimpanan. Penelitian ini dilakukan menggunakan Rancangan Acak Lengkap Faktorial dan terdiri dari 6 ulangan. Perlakuan pertama adalah varietas yang terdiri dari varietas Sangga Sembalun dan varietas Lumbu Kuning, sementara perlakuan kedua adalah bentuk yang terdiri dari bentuk rogol dan konde. Hasil penelitian menunjukkan bahwa tingkat penurunan bobot bawang putih tertinggi yaitu pada saat 1 minggu penyimpanan dengan penurunan sebesar $33,2 \%$ dengan susut diamater sebesar 6,98\%. Bawang putih untuk konsumsi segar ( \pm 2 bulan) dalam bentuk konde memiliki tingkat penurunan yang lebih rendah jika dibandingkan dengan bentuk rogol yaitu sebesar 21,45\% untuk varietas Lumbu Kuning dan 19,88\% untuk varietas Sangga Sembalun. Demikian halnya dengan penyimpanan selama 6 bulan, bawang putih dalam bentuk konde memiliki tingkat kehilangan air yang lebih rendah, tidak cepat keriput dan layu serta kerusakan akibat mikroorganisme dapat lebih diminimalisir.
\end{abstract}

Kata kunci: bawang putih, kualitas, kehilangan berat, penyimpanan.

\begin{abstract}
Garlic is a horticultural commodity that has high economic value and is widely used by the community as a spice or medicine. Garlic has experienced many changes both nutritionally and appearance during storage, so it requires proper postharvest handling. The aimed of this study was to determine the quality of Sangga Sembalun and Lumbu Kuning garlic stored at room temperature for both consumption and seeds as well as to find out the quality of garlic in the form of konde and rogol during storage. This research was conducted using a Factorial Complete Randomized Design and consisted of 6 replications. The first treatment is a variety consisting of
\end{abstract}


Sangga Sembalun and Lumbu Kuning varieties, while the second treatment is a form of garlic consisting of konde and rogol. The results showed that the highest reduction in garlic weight was at 1 week of storage with a decrease of $33.2 \%$ with shrinkage of diameters of $6.98 \%$, because in these conditions the water content of horticultural commodities was still very high. Garlic for fresh consumption (storage for up to 2 months) in the form of conde had a lower rate of decline compared to the form of rogol which is equal to $21.45 \%$ of Lumbu Kuning varieties and $19.88 \%$ for Sangga Sembalun varieties. Likewise with storage for 6 months. Garlic in the form of conde had a lower level of water loss, and better fresh appearance (not wrinkled and withered) and damage due to microorganisms can be minimized.

Keywords: garlic, quality, weight loss, storage.

\section{PENDAHULUAN}

Dalam rangka mendukung program swasembada bawang putih, Badan Litbang Pertanian telah mengeluarkan varietas bawang putih Sangga Sembalun Nomor 79/Kpts/TP.240/2/1995 dengan rata-rata hasil 8,75 $\mathrm{t} \mathrm{ha}^{-1}$ umbi kering dan varietas Lumbu Kuning Nomor 895/Kpts/TP.240 /11/1984 dengan produksi umbi 6-8 $\mathrm{t} \mathrm{ha}^{-1}$. Kedua varietas ini diharapkan dapat bersaing dengan bawang putih impor baik dari segi kualitas, kuantitas maupun harga, sehingga ke depan dapat menurunkan laju impor bawang putih.

Bawang putih memiliki banyak manfaat untuk tubuh menstimulasi kekebalan tubuh, diaplikasikan sebagai bumbu maupun obat. Kandungan senyawa fenolik yang terdapat pada bawang putih memberikan efek sebagai antioksidan dan antibakteri (Wiryawan et al. 2005). Menurut Hernawan dan Setyawan (2003), umbi bawang putih dapat mengobati berbagai macam penyakit seperti tekanan darah tinggi, gangguan pernafasan, sakit kepala, sembelit, luka memar, kolesterol, flu, gangguan saluran kencing dan lain-lain. Bawang putih juga memiliki kandungan senyawa Ajoene yang bersifat antikolesterol, membantu mencegah penggumpalan darah, dan mengecilkan sumbatan pada arteri jantung (Untari 2010).
Setiap $100 \mathrm{~g}$ umbi bawang putih mengandung 4,5 g protein, 0,20 g lemak, $23,10 \mathrm{~g}$ hidrat arang, 0,22 $\mathrm{mg}$ vitamin B1, 15 mg vitamin C, 95 kalori, $134 \mathrm{mg}$ posfor, 42 mg kalsium, $1 \mathrm{mg}$ zat besi dan $71 \mathrm{~g}$ air. Selain itu, umbi bawang putih mengandung zat aktif alisin, enzim alinase, germanium, sativine, sinistrine, selenium, scordinin dan nicotinic acid (Untari 2010). Bawang putih mengandung lebih dari 100 metabolit sekunder yang berperan dalam menentukan rasa, aroma dan sifat-sifat farmakologinya. Zat alisin yang terkandung dalam bawang putih merupakan precursor pembentukan Allil sulfida yang merupakan antioksidan utama dalam bawang putih dan memiliki sifat sebagai antimikroba serta antioksidan.

Bawang putih banyak mengalami perubahan baik secara nutrisional maupun penampakannya selama penyimpanan, sehingga dibutuhkan penanganan pascapanen yang tepat (Adebowale et al. 2012). Menurut Sulistyaningrum dan Darudriyo (2018), kerusakan hortikultura dapat dipercepat bila penanganan selama panen atau sesudah panen kurang baik. Penanganan pascapanen yang tepat akan memperpanjang daya simpan dari bahan pangan. Kajian terkait tingkat penurunan hasil bawang putih selama penyimpanan sangat bermanfaat untuk merancang pengendalian yang tepat baik digunakan 
sebagai bawang konsumsi maupun untuk benih.

Tujuan dari penelitian ini adalah mengetahui kualitas bawang putih Sangga Sembalun dan Lumbu Kuning yang disimpan dalam suhu ruang baik untuk konsumsi maupun benih serta mengetahui kualitas bawang putih dalam bentuk konde maupun rogol selama penyimpanan.

\section{BAHAN DAN METODE}

Penelitian ini dilaksanakan pada tanggal April-Desember 2018, di Pusat Penelitian dan Pengembangan Hortikultura Kecamatan Bogor Barat, Kota Bogor, Jawa Barat. Bahan yang digunakan pada penelitian ini adalah bawang putih varietas Sangga Sembalun yang berasal dari Bima NTT dan varietas Lumbu Kuning yang berasal dari BPTP Jateng.

\section{Penyimpanan bawang putih}

Bawang putih disimpan dalam suhu ruang dengan cara digantung dalam suatu ruangan. Pada umur 1 minggu penyimpanan, sebagian daun bawang putih dipotong untuk membandingkan kualitas bawang putih bentuk konde dan bentuk rogol .

\section{Rancangan Percobaan}

Penelitian ini menggunakan Rancangan Acak Lengkap faktorial dengan 4 kombinasi perlakuan dan diulang 6 kali, sehingga diperoleh 24 unit percobaan. Perlakuan yang diuji pada penelitian ini adalah varietas yang terdiri dari varietas Sangga Sembalun (V1) dan varietas Lumbu Kuning (V2), bentuk bawang putih yang terdiri dari bentuk rogol (B1) dan bentuk konde (B2) serta lama penyimpanan selama satu minggu $(0,1,2,3,4,5,6,7$ hari $)$ dan penyimpanan selama 6 bulan $(0,1,2,3,4,5,6$ bulan).

Peubah yang diamati adalah susut bobot selama 1 minggu (diamati setiap hari), susut bobot 6 bulan, susut diameter dan uji organoleptik yang meliputi warna, kekerasan serta penampakan.

\section{Analisis Data}

Penelitian ini menggunakan analisis regresi linear dengan peubah bebas (X) terdiri atas lama penyimpanan selama satu minggu $(0,1,2,3,4,5,6,7$ hari) dan lama penyimpanan selama enam bulan $(0,1,2,3,4,5,6$ bulan) serta peubah terikat $(Y)$ meliputi susut bobot dan susut diameter. Model matematis penelitian sebagai berikut:

$$
Y=a+b X
$$

Keterangan:

$\mathrm{Y}=$ peubah terikat meliputi susut bobot dan susut diameter

$\mathrm{X}=$ peubah bebas yaitu lama penyimpanan

$\mathrm{A}=$ koefisien regresi yang mencerminkan intersep

$\mathrm{B}=$ koefisien regresi yang mencerminkan kemiringan (gradien)

$\mathrm{R}^{2}=$ koefisien determinasi (menentukan seberapa besar kemampuan model regresi menjelaskan keragaman peubah terikat)

Perhitungan:

$$
\begin{aligned}
& \mathrm{a}=\frac{(\Sigma \mathrm{y})\left(\Sigma \mathrm{x}^{2}\right)-(\Sigma \mathrm{x}) \cdot(\Sigma \mathrm{xy})}{\mathrm{n}\left(\Sigma \mathrm{x}^{2}\right)-(\Sigma \mathrm{x})^{2}} \\
& \mathrm{~b}=\frac{\mathrm{n}(\Sigma \mathrm{xy})-(\Sigma \mathrm{x})(\Sigma \mathrm{y})}{\mathrm{n}\left(\Sigma \mathrm{x}^{2}\right)-(\Sigma \mathrm{x})^{2}} \\
& \mathrm{R}^{2}=\frac{\mathrm{b} \cdot \Sigma \mathrm{xy}}{\Sigma \mathrm{y}^{2}}
\end{aligned}
$$

\section{HASIL DAN PEMBAHASAN}

Pada Tabel 1 terlihat bahwa bawang putih varietas Sangga Sembalun dan varietas Lumbu Kuning memiliki warna kulit luar 
umbi putih kemerahan, dan warna kulit siung berwarna merah keunguan, sedangkan warna umbi kedua varietas ini berwarna putih kekuningan.

Tabel 1 Hasil pengamatan karakteristik fisik dan organoleptik bawang putih Sangga Sembalun dan Lumbu Kuning

\begin{tabular}{|c|c|c|}
\hline Karakteristik fisik & Sangga Sembalun & Lumbu Kuning \\
\hline Warna kulit umbi & $\begin{array}{l}\text { Putih kemerahan-Putih } \\
\text { keunguan }\end{array}$ & $\begin{array}{l}\text { Putih kemerahan- Putih } \\
\text { keunguan }\end{array}$ \\
\hline Warna kulit siung & Merah keunguan & Merah keunguan \\
\hline Warna umbi & Putih kekuningan & Putih kekuningan \\
\hline Jumlah anakan & 4-10 buah & 9-14 buah \\
\hline Berat umbi & $9,1 \mathrm{~g}$ & $34,2 \mathrm{~g}$ \\
\hline Berat siung & $0,79 \mathrm{~g}$ & $2,4 \mathrm{~g}$ \\
\hline Ukuran umbi & Dimensi $3,02 \mathrm{~cm} \mathrm{x} 2,42 \mathrm{~cm}$ & Dimensi $4,78 \mathrm{~cm} \times 4,18 \mathrm{~cm}$ \\
\hline Ukuran siung & Dimensi $1,67 \mathrm{~cm} \times 0,74 \mathrm{~cm}$ & Dimensi $1,61 \mathrm{~cm} \mathrm{x} 1,25 \mathrm{~cm}$ \\
\hline Aroma & Sangat tajam & Sangat tajam \\
\hline Kemudahan dalam mengupas & Tidak mudah & Agak mudah \\
\hline Tekstur & Sangat keras & Sangat keras \\
\hline Penampakan & Mulus & Mulus \\
\hline
\end{tabular}

Bawang putih varietas Lumbu Kuning memiliki bobot umbi yang lebih berat dibandingkan dengan varietas Sangga Sembalun. Bobot rata-rata umbi varietas Lumbu Kuning sebesar 34,2 g, sedangkan varietas Sangga Sembalun sebesar 9,1 g. Hal ini menunjukkan Lumbu Kuning memiliki bobot 375,8\% lebih berat dibandingkan dengan varietas Sangga Sembalun. Varietas Lumbu Kuning memiliki ukuran dimensi umbi $4,78 \mathrm{~cm}$ x 4,18 $\mathrm{cm}$ dan dimensi siung $1,61 \mathrm{~cm} \times 1,25 \mathrm{~cm}$, sedangkan varietas Sangga Sembalun memiliki dimensi umbi $3,02 \mathrm{~cm} \times 2,42 \mathrm{~cm}$ dan dimensi siung $1,67 \mathrm{~cm}$ $\mathrm{x} 0,74 \mathrm{~cm}$. Jumlah anakan varietas Sangga Sembalun rata-rata 4-10 buah dengan bobot siung $0,79 \mathrm{~g}$ per siung, sedangkan varietas Lumbu Kuning memiliki jumlah anakan ratarata 9-14 dengan bobot siung 2,4 g per siung.

Berdasarkan hasil uji organoleptik, kedua varietas bawang putih uji memiliki aroma yang sangat tajam dan tekstur yang keras. Aroma tajam bawang putih berasal dari senyawa organosulfur yang mengandung belerang sehingga aroma bawang putih khas dan tajam (Hernawan dan Setyawan 2003).
Berdasarkan kemudaham dalam mengupas, varietas Lumbu Kuning lebih mudah untuk dikupas dibandingkan dengan varietas Sangga Sembalun. Hal tersebut disebabkan karena ukuran umbi maupun siung dari bawang putih Lumbu Kuning yang jauh lebih besar dibandingkan dengan varietas Sangga Sembalun.

Selama 6 bulan penyimpanan, kedua varietas bawang putih mengalami perubahan warna kulit umbi dari putih kemerahan dan putih keunguan menjadi berwarna putih kekuningan seperti bawang putih impor pada umumnya. Selain itu, terjadi penurunan kekerasan umbi bawang putih dari sangat keras menjadi keras dengan aroma tajam.

Perubahan warna yang terjadi pada kulit luar umbi bawang tersebut disebabkan adanya degradasi senyawa antosianin selama penyimpanan. Kandungan antosianin akan mudah terdegradasi pada temperatur yang tinggi, karena stabilitas antosianin dipengaruhi oleh suhu. Bawang putih yang disimpan akan mengalami respirasi yang menghasilkan $\mathrm{CO}_{2}$ dan panas, sehingga menyebabkan terjadinya perubahan warna 
dari kulit umbi bawang dari ungu kemerahan yang semakin lama memudar menjadi pucat.

Selain itu penampakan dari umbi bawang juga mengalami perubahan dari mulus menjadi berkerut. Peningkatan pelunakan juga disebabkan oleh terjadinya penguapan air dari sel sehingga ruang antar sel menjadi menyatu dan zat pektin yang berada pada ruang antar sel akan saling berkaitan (Julianti 2011). Selama penyimpanan terjadi proses kehilangan air sehingga bawang putih mengalami susut bobot yang berdampak pada penampakan bawang yang berkerut. Kandungan makromolekul (karbohidrat, protein, lemak) yang terkandung dalam suatu bahan pangan akan mengalami proses metabolisme yang menghasilkan karbondioksida, air dan panas (Nurdjannah et al. 2014; Widaningrum et al. 2010).

\section{Pengamatan Selama 1 MSP}

Susut bobot

Selama penyimpanan, bawang putih banyak mengalami perubahan baik karakteristik nutrisi maupun karakteristik fisik dan organoleptiknya. Kandungan air yang tinggi pada awal panen menyebabkan bawang putih mengalami kehilangan berat yang cukup tinggi selama penyimpanan. Berdasarkan hasil pengamatan selama 1 minggu setelah panen terhadap bawang putih Sangga Sembalun menunjukkan bahwa selama penyimpanan 7 hari, susut bobot bawang putih mengalami peningkatan secara linear dengan mengikuti grafik fungsi linear $\mathrm{Y}=4,666 \mathrm{X}+3,925\left(\mathrm{R}^{2}=0,9444\right)$. Hal ini menunjukkan bahwa setiap kenaikan 1 hari penyimpanan akan meningkatkan susut bobot bawang putih sebesar 8,591\% hingga penyimpanan selama 7 hari.

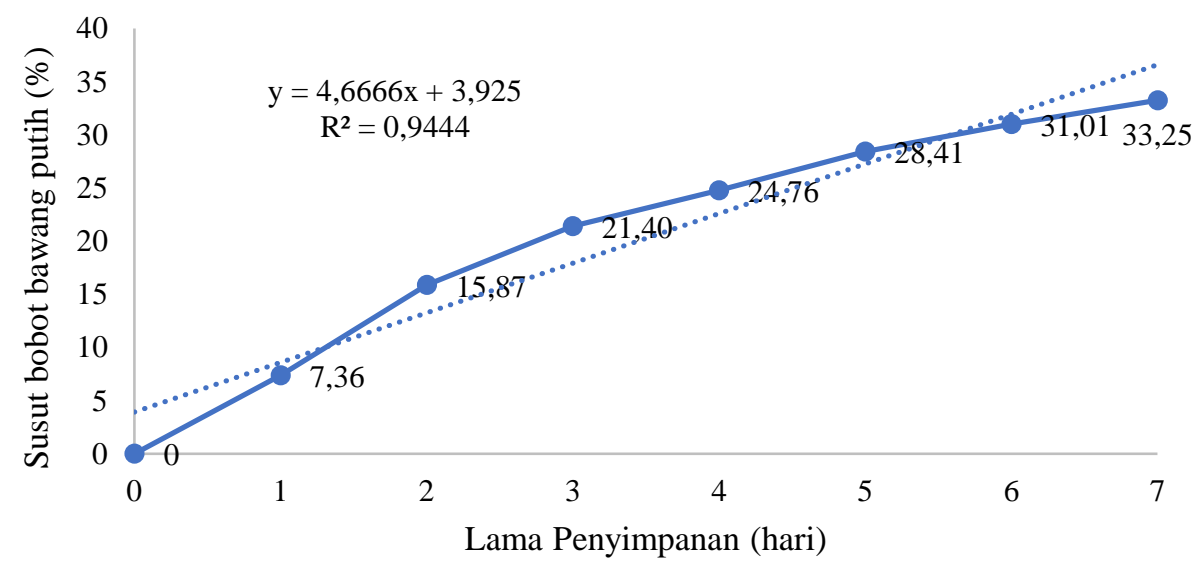

Gambar 1 Susut bobot bawang putih varietas Sangga Sembalun yang disimpan selama seminggu setelah panen dalam suhu ruang

Pada Gambar 1 terlihat bahwa semakin lama penyimpanan menyebabkan kandungan air dari bawang putih mengalami penguapan mengikuti kelembaban udara lingkungan. Menurut Suryanto (2013); Sulistyaningrum dan Komalasari (2016), selama penyimpanan bahan pangan disesuaikan dengan kondisi produknya akan menyerap maupun melepaskan air sehingga terjadi keseimbangan dengan kelembaban udara lingkungan. Tingkat penurunan kadar air tertinggi dari bawang putih yaitu selama 1 minggu terakhir, dengan tingkat penurunan (susut) sebesar 33,25\%. Tingginya losses bawang putih disebabkan kandungan air yang tinggi pada saat awal panen. 
Diameter umbi

Penurunan bobot bawang putih akan selaras dengan penurunan diameter umbi selama penyimpanan dalam suhu ruang. Selama penyimpanan terjadi peningkatan susut diameter umbi bawang dengan mengikuti grafik fungsi linear $\mathrm{Y}=0,925 \mathrm{X}+$ $0,7585\left(\mathrm{R}^{2}=0,968\right)$. Hal ini menunjukkan bahwa setiap kenaikan 1 hari penyimpanan akan meningkatkan susut diameter bawang putih sebesar $1,683 \%$ hingga penyimpanan selama 7 hari.

Berdasarkan Gambar 2 bawang putih yang telah dipanen mengalami susut diameter yang semakin meningkat secara signifikan.
Pada penyimpanan hari ke-7, diameter umbi bawang mengalami susut sebesar 6,98\%. Penurunan diameter bawang ini disebabkan adanya susut bobot akibat kehilangan air selama penyimpanan. Pada saat minggu pertama setelah panen, tingkat kehilangan air pada bahan pangan segar sangat tinggi, karena pada kondisi tersebut kandungan air dari komoditas hortikultura masih sangat tinggi. Menurut Silaban et al (2013), buahbuahan dan sayuran mengalami kehilangan air setelah pemanenan, buah tetap melangsungkan aktifitas metabolisme dengan hilangnya sebagian air melalui transpirasi.

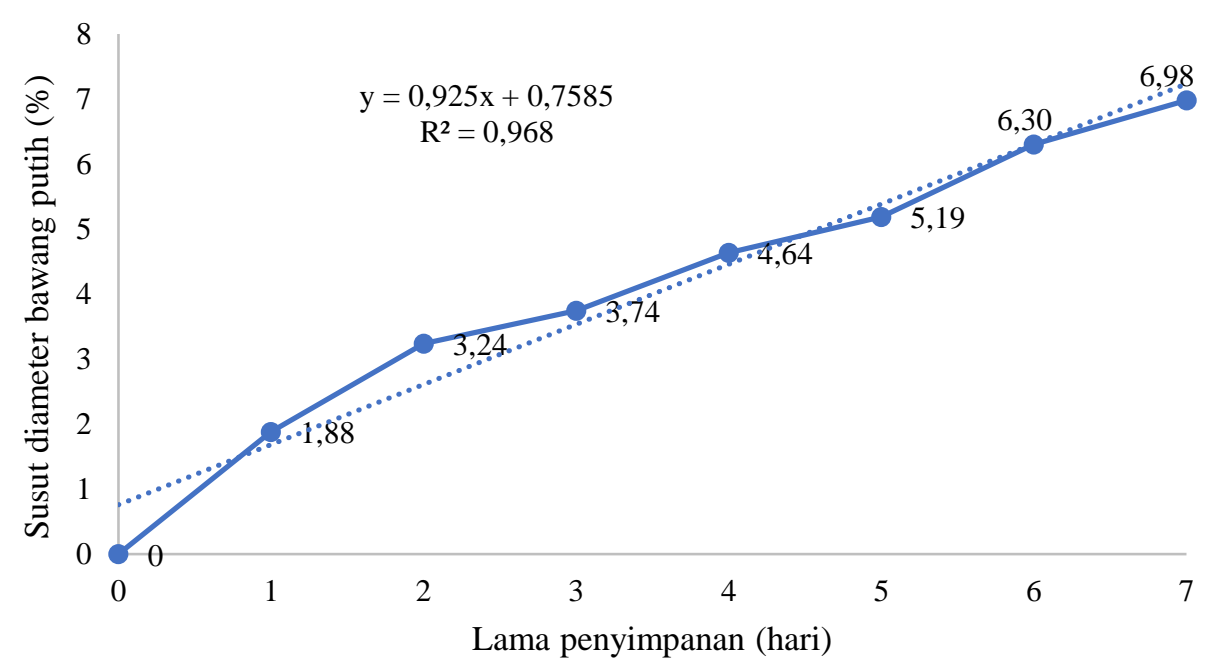

Gambar 2 Susut diameter bawang putih Sangga Sembalun yang disimpan selama seminggu setelah panen dalam dalam suhu ruang

\section{Pengamatan 1 minggu sampai 6 bulan penyimpanan}

Susut bobot bawang putih

Kondisi saat ini petani melakukan penyimpanan bawang putih dalam bentuk konde (daunnya masih terikat) maupun rogol (dipotong daunnya). Perhitungan terkait losses bawang pada kondisi tersebut sangat penting dilakukan untuk melihat perubahan karakteristik bawang putih yang menguntungkan petani baik dari segi kualitas fisik maupun penampakannya. Bawang putih dalam bentuk konde memiliki daya simpan yang lebih baik jika dilihat dari penampakan serta susut bobotnya.

Selama penyimpanan bawang putih dalam bentuk konde baik varietas Sangga Sembalun maupun varietas Lumbu Kuning yang telah berumur seminggu akan mengalami losses (kehilangan berat). Berdasarkan pengamatan setiap bulannya, tingkat penurunan terbesar pada saat bulan ke 
satu pengamatan yaitu sebesar $18,57 \%$ untuk varietas Sangga Sembalun dan 19,19\% untuk varietas Lumbu Kuning. Kemudian pada bulan selanjutnya, bawang putih kedua varietas ini tetap mengalami penurunan tetapi tidak terlalu signifikan setiap bulannya hingga penyimpanan selama 6 bulan. Hal ini dikarenakan kandungan air dalam bawang putih tersebut sudah konstan (kering eskip).

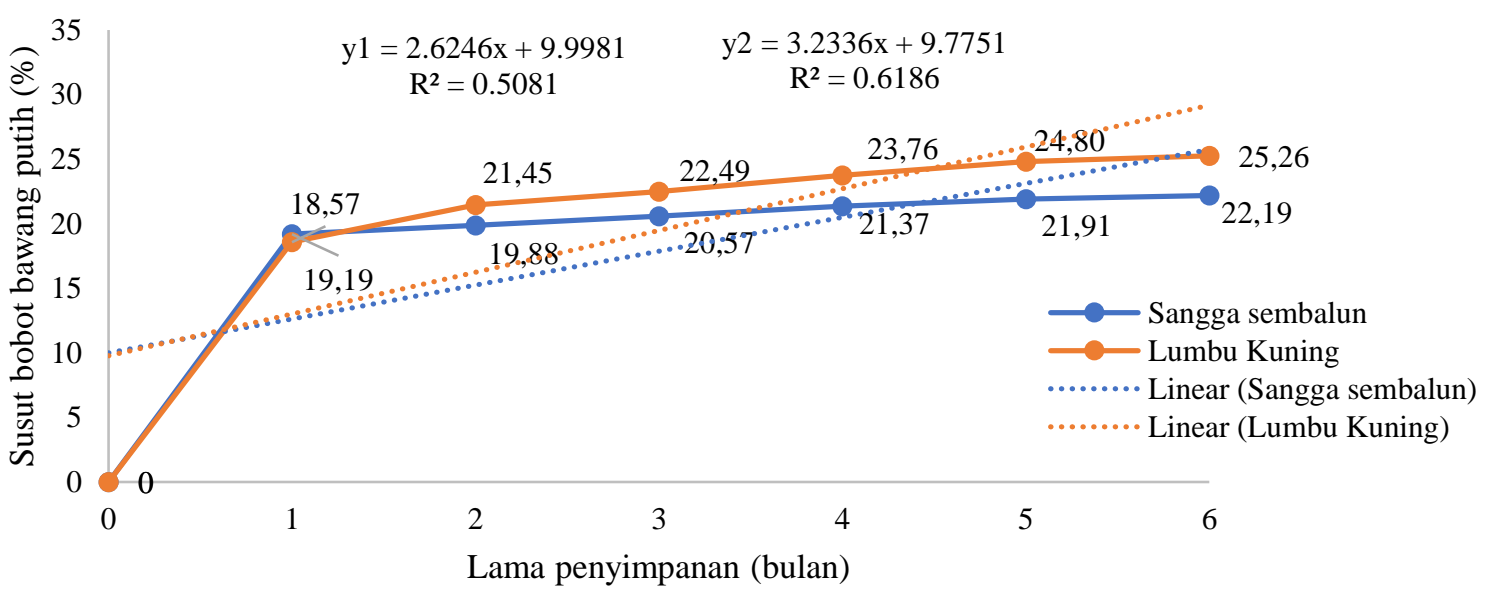

Gambar 3 Susut bobot bawang putih konde umur seminggu yang disimpan selama 6 bulan dalam suhu ruang

Penyimpanan selama 6 bulan, pada bawang putih varietas Lumbu Kuning memiliki tingkat susut yang lebih tinggi yaitu $25,26 \%$ sedangkan varietas Sangga Sembalun sebesar 22,19\%. Hal ini disebabkan pengaruh ukuran umbi dari varietas Lumbu Kuning yang jauh lebih besar jika dbandingkan dengan varietas Sangga sembalun. Semakin besar dimensi dari suatu bahan pangan menunjukkan luas permukaan yang lebih besar, sehingga tingkat penguapannya juga akan lebih tinggi (Adebowale et al. 2012).

Setelah disimpan selama 1 minggu, bawang putih tersebut sebagian dipotong daunnya (bentuk rogol). Dilakukan pengamatan selama 6 bulan untuk melihat perubahan karakteristik fisik dan tingkat kehilangan hasil (susut) dari bawang untuk konsumsi (1-2 bulan penyimpanan) maupun untuk benih ( 6 bulan penyimpanan).

Berdasarkan Gambar 4 menunjukkan bahwa bawang putih Sangga Sembalun yang berumur satu minggu dalam bentuk konde memiliki tingkat losses yang lebih rendah jika dibandingkan dengan bentuk rogol baik untuk bawang konsumsi (penyimpanan 1-2 bulan) maupun untuk benih (penyimpanan 6 bulan). Tingkat penurunan bawang konsumsi terlihat pada saat penyimpanan selama 1 hingga 2 bulan. Pada saat penyimpanan selama satu bulan, terlihat bahwa susut bobot dari bawang putih bentuk rogol sebesar $27,02 \%$ dengan kehilangan daun sebesar $4,68 \%$ dan kehilangan karena sampah (kotoran) sebesar $0,58 \%$. Sehingga tingkat kehilangan air dari bentuk rogol sebesar $21,76 \%$, sedangkan bawang putih konde sebesar 19,19\%. Pada saat penyimpanan selama dua bulan menunjukkan bahwa susut bobot dari bawang bentuk rogol sebesar $27,62 \%$ dengan kehilangan daun sebesar $4,79 \%$ dan kehilangan kotoran (sampah) $0,59 \%$, sehingga tingkat kehilangan air dari bentuk rogol sebesar 22,24\%, sedangkan bawang putih konde sebesar 19,88\%.

Jika dilihat dari losses karena kehilangan air menunjukkan bahwa bawang putih bentuk konde memiliki tingkat losses yang lebih rendah jika dibandingkan dengan 
bentuk rogol. Kandungan air yang tersimpan dalam matriks bahan pangan akan mempengaruhi kualitas yang berdampak pada penampakan dan daya simpan produk. Menurut Sulistyaningrum dan Darudriyo (2017), selama penyimpanan bahan pangan akan mengalami proses respirasi dengan memecah karbohidrat dan oksigen menjadi karbondioksida dan uap air. Hal inilah yang menyebabkan kadar air mengalami penurunan sehingga penampakannya menjadi keriput.

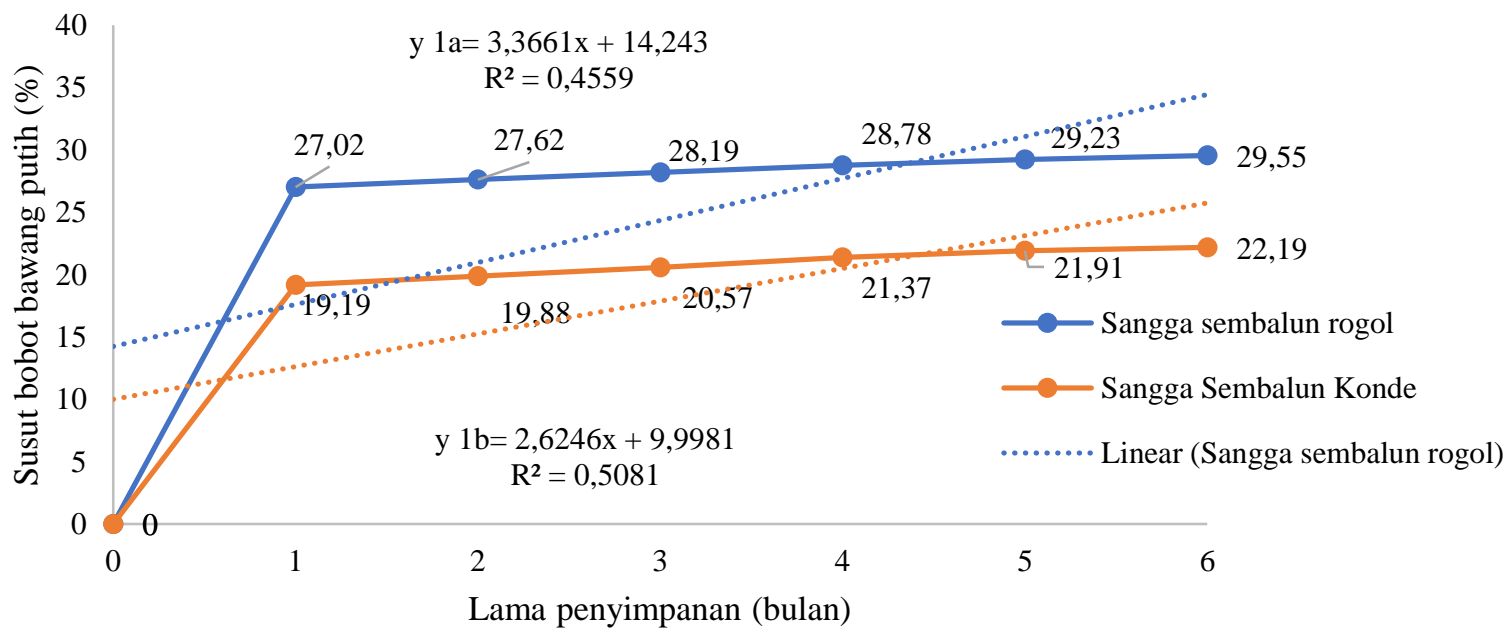

Gambar 4 Susut bobot bawang putih Sangga Sembalun bentuk konde dan rogol umur seminggu yang disimpan selama 6 bulan dalam suhu ruang

Selama penyimpanan 6 bulan, bawang putih dalam bentuk rogol memiliki susut bobot sebesar 29,55\% sedangkan dalam bentuk konde sebesar 22,19\%. Tingkat kehilangan yang tinggi pada bawang putih bentuk rogol disebabkan karena susut kehilangan air serta kehilangan daun. Besarnya kehilangan daun pada saat proses penyimpanan bawang sebesar $5,12 \%$ dan kehilangan karena kotoran (sampah) sebesar $0,63 \%$ sehingga total susut bobot bawang putih rogol karena daun dan kotoran sebesar $5,75 \%$. Perbandingan susut kehilangan air dari bawang putih bentuk rogol sebesar $23,80 \%$ dan bentuk konde sebesar $22,19 \%$. Bawang putih bentuk konde memiliki susut karena kehilangan air yang lebih rendah jika dibandingkan dengan bentuk rogol, hal ini dikarenakan adanya daun yang terikat pada bawang putih akan dapat mengurangi proses transpirasi pada bahan pangan segar, sehingga kehilangan air dapat lebih diminalisir. Menurut Sulistyaningrum dan
Darudriyo (2017), semakin tinggi tingkat kehilangan air akan berpengaruh terhadap tekstur dan penampakannya. Selain itu juga, bawang putih dalam bentuk konde memiliki penampakan kesegaran yang lebih baik (tidak cepat keriput dan layu) serta kerusakan akibat mikroorganisme dapat lebih diminimalisir.

Susut Diameter

Pada Gambar 5 terlihat bahwa bawang putih varietas Lumbu Kuning memiliki tingkat penurunan diameter yang lebih besar jika dibandingkan dengan varietas Sangga Sembalun selama penyimpanan 6 bulan dalam suhu ruang. Terlihat bahwa susut diameter semakin mengalami peningkatan selama penyimpanan dengan mengikuti grafik fungsi linear dengan persamaan untuk varietas Sangga Sembalun $\mathrm{Y} 1=0,7457 \mathrm{X}+0,661\left(\mathrm{R}^{2}=0,946\right)$, sedangkan varietas Lumbu Kuning Y2=0,977X-0,4666 $\left(\mathrm{R}^{2}=0,9502\right)$. 
Besarnya susut diameter sangat erat kaitannya dengan susut bobot dari bawang putih tersebut. Adanya kehilangan air dari komoditas segar akan meningkatkan susut bobot bahan sehingga dimensinya berkurang yang berdampak pada berkurangnya diameter (ukuran) bawang putih tersebut. Selain itu berdasarkan Tabel 1 terlihat bahwa, varietas Lumbu Kuning memiliki ukuran umbi serta ukuran siung yang lebih besar, sehingga luas permukaannya menjadi lebih besar. Hal ini yang menyebabkan tingkat kehilangan air dari varietas tersebut lebih besar. Kandungan air akan mempengaruhi dimensi (panjang, lebar, dan tinggi) dari suatu matrik (Adebowale et al. 2012).

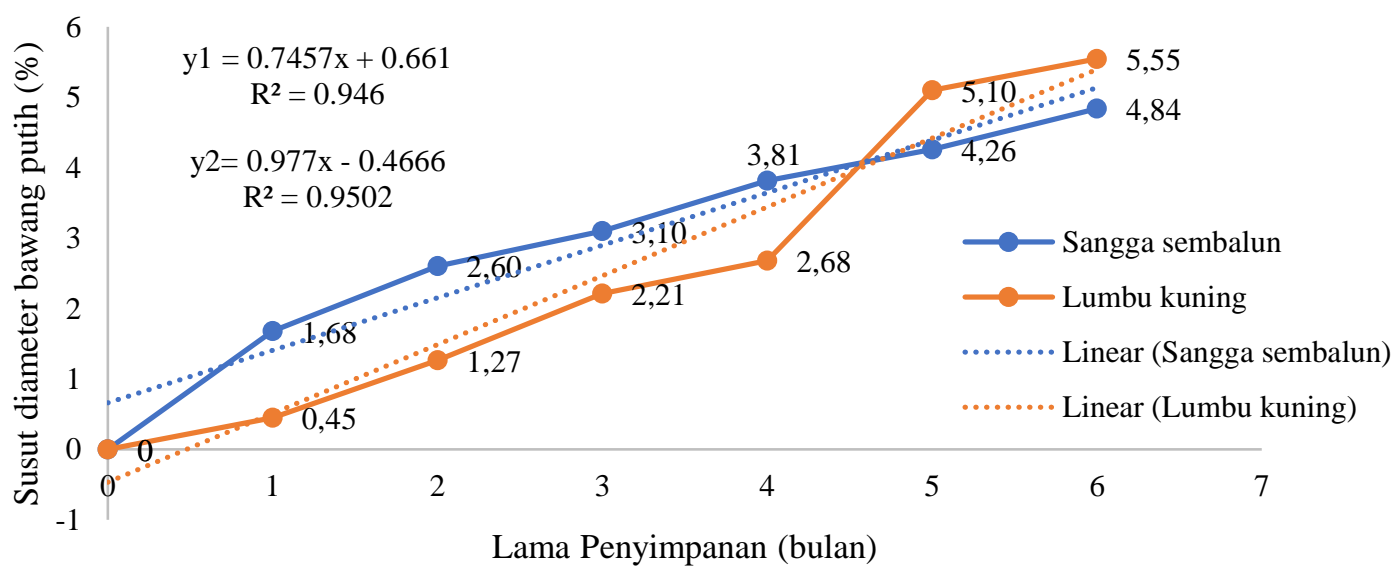

Gambar 5 Susut diameter bawang putih umur seminggu yang disimpan selama 6 bulan dalam suhu ruang

Susut total bawang putih

Besarnya susut bawang putih sangat berpengaruh terhadap tingkat kehilangan hasil dari bawang putih. Sehingga harga jual bawang putih tidak hanya dipengaruhi oleh biaya produksi dari budidaya hingga panen tetapi juga perlu mempertimbangkan pengaruh susut bawang selama panen hingga pascapanennya. Selama penyimpanan satu minggu setelah panen, bawang putih varietas Sangga Sembalun memiliki susut bobot sebesar 33,25\% dengan susut diameter sebesar $6,98 \%$. Tingginya susut bobot ini dikarenakan adanya kehilangan air dari bahan yang menyebabkan berat bawang menurun. Menurut hasil penelitian Sulistyaningrum dan Darudriyo (2018), selama penyimpanan komoditas segar akan tetap melakukan respirasi sehingga susut bobotnya semakin besar.
Pada saat minggu pertama setelah panen, komoditas hortikultura memiliki kandungan air yang cukup tinggi. Kemudian setelah bawang putih berumur satu minggu dilakukan proses pembutikan terhadap sebagian bawang sehingga terdapat bentuk rogol dan konde. Pada penyimpanan selama 1 bulan, menunjukkan bahwa total tingkat kehilangan susut bobot dari panen hingga penyimpanan untuk bawang putih bentuk konde sebesar 52,44\% sedangkan bentuk rogol 55,01\%. Pada penyimpanan selama 2 bulan, menghasilkan tingkat kehilangan dari awal panen sebesar 53,13\% untuk bentuk konde dan 55,49\% untuk bentuk rogol. Susut bobot selama penyimpanan disebabkan oleh proses transpirasi yang menyebabkan terjadinya kehilangan air (Kasmiati et al. 2014). 
Penyimpanan selama 6 bulan, menyebabkan total tingkat kehilangan susut bobot dari panen hingga penyimpanan selama 6 bulan untuk bawang putih Sangga Sembalun bentuk konde sebesar 55,44\%, sedangkan bentuk rogol sebesar 57,05\%. Bawang putih dalam bentuk konde memiliki tingkat kehilangan yang lebih rendah jika dibandingkan dengan bentuk rogol dengan selisih sebesar 1,61\%. Sehingga baik penyimpanan bawang putih selama 1-2 bulan (konsumsi) maupun selama 6 bulan, bawang dalam bentuk konde memiliki susut bobot yang lebih rendah dan daya tahan yang lebih baik (ditinjau dari kesegaran, maupun kerusakan akibat aktivitas mikroorganisme). Tekstur yang semakin lunak menyebabkan penampakan menjadi keriput. Aktivitas mikroorganisme dan enzimatik akan mempengaruhi penampakan dari suatu bahan pangan (Rosalina dan Silvia 2015).

Pada saat penyimpanan hingga 6 bulan bawang putih tidak mengalami kebusukan (hanya berubah penampakan menjadi keriput. Hal ini dikarenakan pada bawang putih mengandung senyawa organosfulfur yang dapat bersifat sebagai antimikroba. Menurut Sulistyaningrum et al. (2015) dan Naufalin et al. (2013), kandungan senyawa bioaktif akan mencegah aktivitas mikroba sehingga kerusakan dapat dihambat. Kandungan senyawa alisin dari bawang putih mempunyai daya hambat yang luas terhadap bakteri, protozoa, virus, dan jamur. Zat alisin mempunyai permeabilitas yang tinggi dalam menembus membran fosfolipid dinding sel bakteri (Untari 2010).

\section{KESIMPULAN}

Semakin lama penyimpanan susut bobot dan susut diameter bawang putih semakin meningkat. Susut tertinggi pada penyimpanan 1 minggu setelah panen, hal ini dikarenakan kandungan air setelah panen cukup tinggi. Pada bawang putih Sangga
Sembalun mengalami susut bobot sebesar $33,25 \%$ dengan susut diameter sebesar $6,98 \%$. Bawang putih dalam bentuk konde memiliki tingkat penurunan susut yang lebih rendah jika dibanding dengan bentuk rogol hingga penyimpanan bulan ke enam. Bawang putih untuk konsumsi segar (penyimpanan hingga 2 bulan) dalam bentuk konde memiliki tingkat penurunan yang lebih rendah jika dibandingkan dengan bentuk rogol yaitu sebesar 21,45\% varietas Lumbu kuning dan 19,88\% untuk varietas Sangga Sembalun. Demikian halnya dengan penyimpanan selama 6 bulan. Bawang putih dalam bentuk konde memiliki tingkat kehilangan air yang lebih rendah, serta memiliki penampakan kesegaran yang lebih baik (tidak cepat keriput dan layu) serta kerusakan akibat mikroorganisme dapat lebih diminimalisir.

\section{DAFTAR PUSTAKA}

Adebowale AA, Fetuga GO, Apata CB, Sanni LO. 2012. Effect of variety and initial moisture content on physical properties of improved millet grains. Nigerian Food Journal 30(1): 5-10.

Hernawan UE, Setyawan AD. 2003. Senyawa organosulfur bawang putih (Allium sativum L.) dan aktivitas biologinya. J. Biofarmasi 1 (2): 6576.

Julianti E. 2011. Pengaruh tingkat kematangan dan suhu penyimpanan terhadap mutu buah terong belanda (Cyphomandra betacea). J. Hort. Indonesia 2(1):14-20.

Kasmiati E, Darmawati E, dan Haryadi Y. 2014. Evaluasi efek kemasan plastik terhadap daya simpan beras. $J$. Pascapanen 11 (1) : 9-18.

Naufalin R, Yanto T, Sulistyaningrum A. 2013. Pengaruh jenis dan konsentrasi pengawet alami terhadap mutu gula 
kelapa. J. Teknologi Pertanian 14 (3): 165-174.

Nurdjannah R, Purwanto YA, Sutrisno. 2014. Pengaruh jenis kemasan dan penyimpanan dingin terhadap mutu fisik cabai merah. J. Pascapanen 11(1): 19-29.

Rosalina Y, Silvia E. 2015. Kajian perubahan mutu selama penyimpanan dan pendugaan umur simpan keripik ikan beledang dalam kemasan polypropylene rigid. J. Teknologi dan Industri Pertanian Indonesia 7(1): 160.

Silaban SD, Prihastanti E, Saptiningsih E. 2013. Pengaruh suhu dan lama penyimpanan terhadap kandungan total asam. Buletin Anatomi dan Fisiologi 11(1): 55-63.

Sulistyaningrum A, Yanto T, Naufalin R. 2015. Perubahan kualitas nira kelapa akibat penambahan pengawet alami. J. Penelitian Pascapanen Pertanian. 12 (3):137 146.

Sulistyaningrum A, Komalasari O. 2016. Pengaruh kualitas benih jagung pada berbagai ruang penyimpanan terhadap vigor benih. Prosiding Seminar Nasional Biologi Universitas Hasanudin, Makassar.
Analisis Regresi Penampilan Bawang Putih Sangga Sembalun dan Lumbu Kuning

Sulistyaningrum A, Darudriyo. 2017. Teknologi penyimpanan sederhana dalam mempertahankan daya simpan terung. Prosiding Seminar Universitas Nasional.

Sulistyaningrum A, Darudriyo. 2018. Penurunan kualitas cabai rawit selama penyimpanan dalam suhu ruang. J. Agronida 4 (2):64-71.

Suryanto, H. 2013. Pengaruh beberapa perlakuan penyimpanan terhadap perkecambahan benih suren (Toona sureni). J. Penelitian Kehutanan Wallacea 2 (1) : 26-40.

Untari I. 2010. Bawang putih sebagai obat paling mujarab bagi kesehatan. Gaster 7 (1): 547-554.

Widaningrum, Miskiyah, Somantri AS. 2010. Perubahan sifat fisiko-kimia biji jagung pada penyimpanan dengan perlakuan karbondioksida $\left(\mathrm{CO}_{2}\right) . J$. Agritech. 30(1): 36-45.

Wiryawan, Suharti S, Bintang M. 2005. Kajian antibakteri temulawak, jahe dan bawang putih terhadap Salmonella lyphimuriam serta pengaruh bawang putih terhadap performans dan respon imun ayam pedaging. J. Media Peternakan 28 (2): 52-62. 